\title{
PERAN SIPUT TEREBRALIA (Gastropoda: Potamididae) DALAM MENGURAI DAUN MANGROVE RHIZOPORA DI PULAU PANJANG, SERANG-BANTEN
}

\section{THE ROLE OF CUT TEREBRALIA (Gastropoda: Potamididae) IN REDUCING MANGROVE LEAF RHIZOPORA IN THE ISLAND, SERANG-BANTEN}

\author{
Selvianti Asmara Putri dan Mufti Petala Patria\# \\ Departemen Biologi, Fakultas Matematika dan Ilmu Pengetahuan Alam, Universitas Indonesia, \\ Kampus Baru UI, Depok 16424 \\ E-mail: mpatria@ui.ac.id
}

(Diterima: 15 Desember 2018; Diterima setelah perbaikan: 9 Januari 2019; Disetujui: 16 Januari 2019)

\begin{abstract}
ABSTRAK
Penelitian mengenai peran siput Terebralia dalam mengurai daun mangrove telah dilakukan pada bulan November hingga Desember 2013 di Pulau Panjang, Banten. Dalam penelitian ini, aktivitas penguraian daun dilakukan pada mangrove yang didominasi oleh Rhizopora sp. Lokasi penelitian terletak di bagian intertidal yang merupakan bagian mangrove yang terkena pasang surut air laut. Penelitian yang dilakukan hanya menggunakan Terebralia dewasa yaitu, Terebralia palustris $>5$ cmdan Terebralia sulcata $>3 \mathrm{~cm}$. Rata-rata persentase penguraian daun oleh $T$. palustris adalah sebesar $3,48 \% \pm 0,18$ /hari untuk $R$. apiculata dan $8,28 \% \pm 0,13$ /hari untuk $R$. stylosa, sedangkan . sulcata mengurai daun rata-rata sebesar $4,07 \% \pm$ 0,12 /hari untuk $R$. apiculata dan 4,93\% $\pm 0,15$ /hari untuk $R$. stylosa. Hasil penelitian juga menunjukkan bahwa tidak ditemukan korelasi $(\mathrm{P}=0,985 ; \mathrm{P}=0,875)$ antara panjang dan berat T.palustris dengan persentase penguraiannya. Begitu pula dengan T.sulcata, tidak ditemukan korelasi antara berat dengan laju penguraiannya. Sebaliknya, terdapat korelasi antara panjang dengan persentase penguraiannya $(\mathrm{P}=$ $0,016)$.
\end{abstract}

KATA KUNCI: Terebralia palustris; Terebralia sulcata; penguraian daun; mangrove

\begin{abstract}
The research about the role of snail Terebralia on leaf litter removal was held on November until December 2013. In this research, litter removal activity was determined on mangrove which was dominated by Rhizopora sp. The mangrove was located in intertidal part which hit by low tide of sea.The research was conducted only used adult Terebralia, such as Terebralia palustris $>5 \mathrm{~cm}$ and Terebralia sulcata $>3 \mathrm{~cm}$. The result of research indicated that the mean of percentage for litter removal activity T. Palustrisfor $\mathrm{R}$. ApiculataandRhizopora stylosawere 3,48\% $\pm 0,18$ day, and $8,28 \% \pm 0,13 /$ day, while $\mathrm{T}$. sulcatafor $\mathrm{R}$. Apiculataand R. stylosawere $4,07 \% \pm 0,12$ /day, and4,93\% 0,15/day respectivelly.There was no correlation between length and weight T. palustris with it litter removal percentage $(P=0,985 ; P=0,875)$. The result also showed that there was no correlation between weight of T. sulcata and it litter removal percentage. The other way, there was correlation between length of T. sulcata and its' litter removal percentage $(P=0,016)$.
\end{abstract}

KEYWORDS: Terebralia palustris; Terebralia sulcata; leaf litter removal; mangrove

\footnotetext{
\# Korespondensi: Universitas Indonesia

E-mail: mpatria@ui.ac.id
} 


\section{PENDAHULUAN}

Hutan mangrove sering dikategorikan sebagai salah satu ekosistem yang paling produktif di perairan tropik (Tue et al. 2012) dan penyimpan karbon tertinggi dari setiap tipe hutan (Kauffman \& Donato, 2012). Cadangan karbon tersebut salah satunya disimpan dalam bentuk biomassa seperti batang, ranting, tajuk, dan daun. Serasah daun mangrove merupakan salah satu tempat penyimpanan cadangan karbon. Daun yang jatuh ke lantai mangrove akan terurai secara alami oleh bakteri dan dekomposer dengan bantuan beberapa fauna.

Salah satu fauna yang memakan daun mangrove adalah dari taksa Avertebrata seperti moluska (Cannicci et al., 2008; Tue et al., 2012). Dalam hutan mangrove, moluska menempati semua level pada jaring-jaring makanan yaitu sebagai predator, herbivora, dan filter feeders (Cannicci et al., 2008). Moluska khususnya Gastropoda merupakan kelompok Avertebrata yang paling dominan dalam ekosistem hutan mangrove (Tue et al., 2012).

Salah satu jenis gastropoda yang memiliki kemampuan dalam memecah atau menghancurkan daun mangrove yang baru jatuh untuk dimakan adalah dari jenis Terebralia (Gastropoda: Potamididae) (Slim et al. 1997; Pramudji 2001; Wells 2003; Fratini et al. 2004). Terebralia merupakan spesies yang aktif baik dalam keadaan air laut pasang maupun keadaan ketika air laut surut (Fratini et al. 2001). Meskipun memiliki kemampuan layaknya amphibi, T. palustris lebih menyukai kondisi lingkungan yang basah (Fratini et al. 2001).

Fratini et al. (2004) menemukan bahwa T. palustris dengan ukuran lebih dari $6 \mathrm{~cm}$ (dewasa) secara aktif mengonsumsi daun mangrove. Laporan yang sama juga ditunjukkan oleh Tue et al. (2012) yang menyatakan bahwa $T$. sulcata dengan ukuran yang lebih besar dari $3 \mathrm{~cm}$ aktif mengonsumsi daun mangrove. Terebralia sulcata ukuran kecil lebih banyak mengonsumsi fitoplankton laut, sedangkan $T$. sulcata dewasa lebih banyak mengonsumsi mangrove (Kandelia obovata, Aegiceras corniculatum, dan Sonneratia caseolaris). Hal tersebut dibuktikan dengan menggunakan metode analisis isi perut (Fratini et al., 2004), dan analisis isotop karbon (Slim et al., 1997). Teknik isotop karbon telah terbukti digunakan sebagai indikator dari sumber bahan organik yang dikonsumsi oleh konsumer (Bouillon et al. 2008). Perbedaan makanan yang dikonsumsi Terebralia muda dan dewasa berkaitan erat dengan perbedaan anatomi dalam struktur radula (Houbrick, 1991).

Salah satu kawasan ekosistem mangrove di Indonesia adalah di Pulau Panjang, Serang-Banten. Pulau
Panjang memiliki luas wilayah sekitar \pm 820 Ha yang menjadikan pulau tersebut sebagai pulau terbesar di perairan Teluk Banten (Lestarina 2011). Keadaan Pulau Panjang yang semakin terancam dengan adanya peningkatan pembangunan di sekitar Teluk Banten dapat mengakibatkan peningkatan tekanan terhadap kualitas ekosistem mangrove dan mengganggu proses ekologi di dalamnya terutama dalam penyerapan karbon (Lestarina, 2011).

Hutan mangrove Pulau Panjang di bagian barat didominasi oleh Rhizopora stylosa dengan jumlah tegakan 49 per $100 \mathrm{~m}^{2}$ dan Rhizopora apiculata dengan jumlah tegakan 116 per $100 \mathrm{~m}^{2}$. Produksi daun $R$. apiculata dan $R$. stylosa mencapai $0,510 \mathrm{~g} / \mathrm{m}^{2} / \mathrm{hari}$. Produksi serasah yang dimaksud mencakup daun, ranting, dan organ reproduksi (Lestarina, 2011). Di Hutan Mangrove tersebut juga ditemukan keang T. palustris dan T. sulcata (Patria \& Putri, 2017).

Dari penjelasan yang telah dijabarkan, penelitian ini dilakukan dengan tujuan untuk (1) mengetahui berapa besar kemampuanT. palustris dan T. sulcata dalam mengurai daun mangrove $R$. apiculata dan $R$. stylosa di Pulau Panjang. (2) Mengetahui korelasi panjang dan berat siput terhadap kemampuan mengurai daun mangrove.

\section{BAHAN DAN METODE}

\section{Waktu dan Lokasi Penelitian}

Penelitian dilaksanakan di kawasan hutan mangrove Pulau Panjang, Kecamatan Bojonegara, Kabupaten Serang, Provinsi Banten. Lokasi penelitian berada pada koordinat $6^{\circ} 25^{\prime} 18^{\prime \prime}-6^{\circ} 28^{\prime} 12^{\prime \prime}$ lintang selatan dan $106^{\circ} 22^{\prime} 9^{\prime \prime}-106^{\circ} 25^{\prime} 36^{\prime \prime}$ bujur timur. Waktu penelitian telah dilaksanakan pada bulan November hingga Desember 2013.

\section{Alat dan Bahan}

Alat dan bahan yang dipergunakan dalam penelitian meliputi tali rafia, jangka sorong, timbangan analitik, gunting, GPS (Global Positioning System), kantung plastik, spidol, jaring berbahan nilon dengan mata jaring (mesh size) $1 \mathrm{~mm}^{2}$, termometer, $\mathrm{pH}$ meter, DO meter, kertas label, dan kamera.

\section{Cara Kerja}

\section{Pengambilan Data}

Siput T. palustris dan T. sulcata yang umumnya terdapat di sekitar pohon mangrove diambil dengan menggunakan tangan. Panjang siput diukur menggunakan jangka sorong, sedangkan berat siput diukur menggunakan timbangan analitik. Siput yang diambil adalah siput dewasa dengan ukuran yaitu $T$. 
palustris $>5 \mathrm{~cm}$ dan T. sulcata $>3 \mathrm{~cm}$. Penggunaan ukuran tersebut berdasarkan pada penelitian sebelumnya (Slim et al., 1997; Tue et al., 2012) yang menyatakan bahwa siput dewasa lebih aktif memakan mangrove.

\section{Eksperimen Lapangan}

Dilakukan eksperimen di wilayah mangrove bagian intertidal dengan menggunakan jaring yang telah dimodifikasi (Gambar1).Jaring termodifikasi berfungsi sebagai kandang untuk eksperimen. Kandang dibuat sebanyak 60 buah. Daun yang sudah tua (berwarna kuning) dariRhizopora apiculata dan Rhizopora stylosadiambil kurang dari 24 jam sebelum eksperimen. Daun tersebut kemudian dikeringkan dan masing-masing dimasukan ke 30 kandang dengan berat awal yang telah diukur. Satu ekor T. palustris dewasa $(>5 \mathrm{~cm}$ )masing-masing dimasukan ke dalam 10 kandang berisi $R$. apiculata dan 10 kandang berisi $R$. stylosa. Selanjutnya, satu ekor $T$. sulcata dewasa ( $>3$ $\mathrm{cm})$ masing-masingdimasukan ke 10 kandang berisi $R$. apiculata dan 10 kandang berisi $R$. stylosa. Dua puluh kandang yang tersisa kemudian dijadikan sebagai kontrol tanpa dimasukan siput. Kandang kemudian ditempatkan di wilayah mangrove bagian intertidal. Eksperimen dilakukan selama 1 x 24 jam dimulai pukul 11.00 WIB. Setelah 24 jam, daun diambil dari semua kandang, dikeringkan dan diukur beratnya.

\section{Analisis Data}

Persentase penguraian daun diperoleh dengan menggunakan rumus sebagai berikut (Boonruang, 1984):

$$
\mathrm{Y}=\frac{\mathrm{BA}-\mathrm{BK}}{\mathrm{BA}} \times 100 \%
$$

Keterangan :

$Y=$ Persentase daun yang mengalami penguraian

$\mathrm{BA}=$ Berat kering daun awal $(\mathrm{g})$

$\mathrm{BK}=$ Berat kering daun setelah waktu pengamatan ke-t (g)

Kecepatan penguraian daun diperoleh dengan menggunakan rumus sebagai berikut:

$$
\ln \frac{\mathrm{Xt}}{\mathrm{Xo}}=-\mathrm{k.t}
$$

Keterangan :

$\mathrm{X}_{\mathrm{t}}=$ Bobot kering seresah setelah waktu pengamatan ke-t $(\mathrm{g})$

$\mathrm{X}_{\mathrm{o}}=$ Bobot seresah awal $(\mathrm{g})$

$\mathrm{k}$ = Laju dekomposisi seresah

$\mathrm{t}$ = waktu pengamatan (hari)

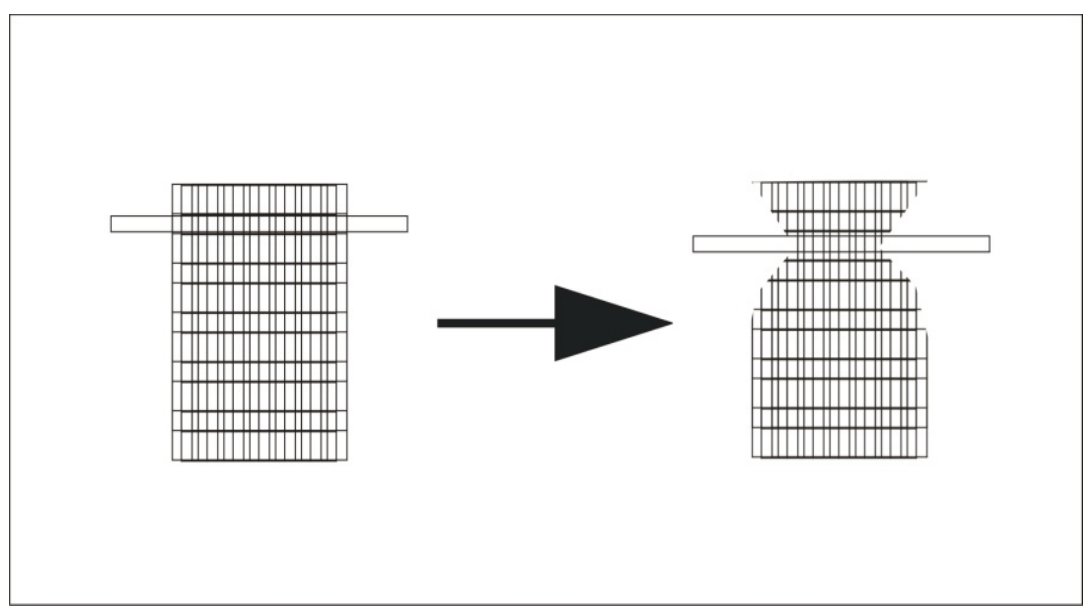

Gambar 1. Jaring yang dimodifikasi menjadi kantung dengan ukuran $20 \times 30 \mathrm{~cm}$, dengan bagian atas dapat diikat.

Figure 1. Nets that are modified into bags with a size of 20x30 cm, with the upper part can be tied.

\section{HASIL DAN PEMBAHASAN}

\section{Persentase Penguraian Daun oleh $T$. palustris dan T. sulcata}

Dari hasil eksperimen, rata-rata persentase penguraian daun oleh T. palustris adalah sebesar 3,48\% $\pm 0,18$ /hari untuk $R$. apiculata dan $8,28 \% \pm 0,13$ /hari untuk $R$. stylosa. Sedangkan T. sulcata mengurai daun rata-rata sebesar $4,07 \% \pm 0,12 /$ hari untuk $R$. apiculata dan $4,93 \% \pm 0,15$ /hari untuk $R$. stylosa. Persentase penguraian daun ditunjukkan pada Tabel 1. Hasil tersebut didapatkan dari persentase penguraian daunoleh masing-masing siput dikurangi kontrol (Lampiran 1 dan 2). Sedangkan kecepatan dekomposisi daun mangrove ditunjukkan pada Tabel 2 . 
Berdasarkan analisis persamaan linier (Tabel 3) didapatkan bahwa tidak ada korelasi antara panjang maupun berat $T$. palustris terhadap persentase penguraiannya. Begitu pula dengan T. sulcata, tidak ditemukan korelasi antara berat terhadap laju penguraiannya. Sebaliknya, terdapat korelasi antara panjang dengan persentase penguraiannya.

Tabel 1. Persentase Penguraian Daun (\%) dalam 24 jam

Table 1. Percentage of Decomposition of Leaves (\%) in 24 hours

\begin{tabular}{llll}
\hline Perlakuan & T. palustris & T. sulcata & Kontrol \\
\hline R. apiculata & $26,62 \pm 0,18$ & $27,21 \pm 0,12$ & $23,14 \pm 0,08$ \\
R. stylosa & $29,70 \pm 0,13$ & $26,35 \pm 0,15$ & $21,42 \pm 0,12$ \\
\hline
\end{tabular}

Tabel 2. Kecepatan Penguraian Daun(ghari $\left.{ }^{-1}\right)$

Table 2. Speed of Decomposition of Leaves (g day-1)

\begin{tabular}{lccc}
\hline \multicolumn{1}{c}{ Perlakuan } & T. palustris & T. sulcata & Kontrol \\
\hline R. apiculata & $0.34 \pm 0,28$ & $0.33 \pm 0,12$ & $0.25 \pm 0,11$ \\
R. stylosa & $0.36 \pm 0,19$ & $0.32 \pm 0,21$ & $0.26 \pm 0,16$ \\
\hline
\end{tabular}

Tabel 3. Persamaan Linier dan Analisis Korelasi Panjang dan Berat Kedua Jenis Terebralia terhadap Persentase Penguraian

Table 3. Linear Equations and Analysis of the Correlations of the Lengths and Weight of the Two Types to the Percentage of Decomposition

\begin{tabular}{llcc}
\hline \multicolumn{2}{c}{ Parameter } & $\mathbf{R}^{2}$ & p-value \\
\hline T. palustris & Panjang & 0,001 & 0,985 \\
& Berat & 0,001 & 0,875 \\
T. sulcata & Panjang & 0,181 & 0,016 \\
& Berat & 0,144 & 0,115 \\
\hline
\end{tabular}

\section{Persentase Penguraian Daun oleh siput}

Seresah mangrove merupakan sumber utama nutrisi dan bahan organik ke sistem perairan pesisir. Daun pada suatu ekosistem mangrove setelah mengalami dekomposisi sangat penting artinya untuk perikanan pantai karena ekosistem mangrove menyediakan bahan makanan bagi berbagai spesies, termasuk siput Terebralia. Hasil eksperimen penguraian seresah mangrove $R$. apiculata dan $R$. stylosa oleh T. palustris dan T. sulcata dalam waktu 24 jam menunjukkan bahwa Terebralia lebih aktif memakan daun $R$. stylosa. Tabel 1 menunjukkan bahwa T. palustris dan T. sulcata aktif memakan daun $R$. stylosa sebesar 8,28\% dan 4,93\% lebih banyak dibandingkan dengan daun $R$. apiculata.

Ashton et al. (1999) mengungkapkan bahwa perbedaan laju penguraian berkaitan dengan morfologi, tekstur, dan komposisi daun serta berkaitan dengan konsentrasi tanin dan nilai nutrisi pada daun sebagai pakan. Daun $R$. stylosa memiliki struktur morfologi permukaan daun yang lebih licin, lebih tebal dan lebih lebar. Sedangkan permukaan daun $R$. apiculata memiliki tekstur yang cenderung kasar dan tipis.
Diduga kedua jenis Terebralia lebih banyak memakan daun R.stylosa dikarenakan teksturnya yang lebih mudah dimakan. Hal ini juga dapat terlihat pada Tabel 2 yang menunjukkan bahwa T. palustris lebih cepat mendekomposisi daun $R$. stylosa. Sedangkan $T$. sulcata memiliki kecepatan dekomposisi yang hampir sama antara daun $R$. apiculata dengan $R$. stylosa.

Tabel 1 memperlihatkan bahwa pada kandang yang tidak berisi siput terjadi juga proses penguraian yang merupakan proses penguraian alami. Choong et al. (1992) menyatakan bahwa tingginya persentase seresah yang terurai secara alami dikarenakan kehilangan bahan-bahan organik seresah yang larut. Hal tersebut terjadi biasanya diwaktu awal ketika daun gugur. Hal lainnya menurut Mason (2004), terjadinya penguraian alami diduga karena proses penguraian juga dibantu oleh mekanisme fisik yaitu, pergerakan arus pasang dan penggenangan air laut yang lebih lama. Dalam penelitian ini, eksperimen dilakukan pada pukul 11.00 WIB hingga pukul 11.00 keesokan harinya. Pada waktu itu, kondisi lokasi penelitian baik pada saat mulai maupun selesai ekperimen tergenang air pasang.

Kondisi penelitian dimana lokasi eksperimen 
dilakukan lebih banyak pada saat tergenang air, kemungkinan tidak memengaruhi aktifitas makan bagi Terebralia. Hal tersebut ditegaskan dengan hasil penelitian Fratini et al. (2004) yang menunjukkan bahwa waktu aktif makan Terebralia tidak tergantung pasang surut air laut dan waktu (siang atau malam).

Hasil penelitian menjelaskan bahwa kedua spesies Terebralia dapat mengurai mangrove baik $R$. apiculata maupun $R$. stylosa. Hasil tersebut dipertegas dengan penelitian sebelumnya yang menggunakan analisis stabil isotop karbon untuk mengetahui sumber makanan T. palustris maupun T. sulcata. Teknik isotop stabil secara alami berhasil digunakan pada penelitian ekofisiologi tumbuhan dan tanah (Griffiths, 1998). Tidak hanya itu, teknik tersebut juga berhasil dilakukan untuk penelitian ekologi hewan (Schmidt et al., 1999). Hasil positif dari isotop stabil adalah perbandingan isotop $\mathrm{C}$ dari konsumer sama dengan perbandingan isotop makanan yang dikonsumsinya (McCutchan et al., 2003).

Penelitian sebelumnya, menunjukkan bahwa genus Terebralia memiliki nilai rata-rata ${ }^{13} \mathrm{C}$ sebesar $-21,3 \%$ (Slim et al. 1997). Nilai tersebut tidak berbeda jauh dengan nilai rata-rata ${ }^{13} \mathrm{C}$ mangrove Rhizoporaceae sebesar -27,5 $\pm 0,5 \%$ (Penha-Lopes et al., 2009). Menurut Bouillon et al. (2008), jarak positif nilai stabil isotop antara sumber pakan dengan konsumer adalah $\sim 6 \%$. Oleh sebab itu, hasil mengindikasikan bahwa mangrove berkontribusi sebagai sumber makanan bagi Terebralia dewasa. Pada beberapa penelitian sebelumnya, disebutkan bahwa genus Terebralia mampu hidup tanpa makanan hingga empat bulan (Rao, 1998), sementara Soemodihardjo dan Kastoro (1977) menemukan bahwa siput Terebralia dapat hidup tanpa air dan makanan selama tiga bulan.

Pada penelitian sebelumnya diketahui bahwa $T$. palustris dewasa secara aktif mengurai serasah daun mangrove yang jatuh ke lantai hutan. Berbeda dengan T. palustris muda yang umumnya merupakan filter feeder (Houbrick, 1991; Slim et al., 1997; Fratini et al., 2004; Penha-Lopes et al., 2009). Perbedaan sumber makanan antara Terebralia dewasa dan Terebralia muda diyakini karena adanya perubahan morfologi radula (Houbrick, 1991).

Pada penelitian ini, eksperimen dimulai pada saat air laut dalam keadaan pasang. Dengan harapan bahwa Terebralia terhindar dari kemungkinan stress akibat kekeringan. Telah diketahui sebelumnya bahwa lingkungan merupakan salah satu faktor yang mempengaruhi jumlah daun $R$. apiculata dan $R$. stylosa yang diurai oleh Terebralia. Jumlah persentase penguraian daun mangrove yang tinggi umumnya terjadi pada saat kondisi air laut pasang atau hujan. Ketika Terebralia dalam kondisi tidak tergenang (air laut surut), siput akan lebih malas untuk beraktivitas atau bergerak. Hal tersebut dilakukan untuk menghemat air yang terdapat dalam tubuh Terebralia. Terebralia juga akan berusaha menghindari cahaya matahari secara langsung agar tidak mengenai bagian tubuh lunaknya. Adanya kelompok-kelompok Terebraliayang bersembunyi di bawah bayangan pohon mangrove dan tanah berlumpur merupakan salah satu bukti perilaku Terebralia untuk menghindari dessication dan thermal stress (Slim et al., 1997).

\section{Korelasi Berat dan Panjang Siput terhadap Persentase Penguraian}

Hasil analisis uji statistik, tidak terdapat korelasi antara berat dan panjang $T$. palustris terhadap persentase penguraiannya. Begitu pula dengan $T$. sulcata, tidak terdapat korelasi antara berat dengan persentase penguraiannya. Sebaliknya terdapat korelasi ( $\mathrm{P}=0,016, \mathrm{n}=20$ ) antara panjang $T$. sulcata dengan persentase penguraian.

Jika melihat pada hasil analisi korelasi antara panjang dengan berat, terlihat bahwa semakin panjang ukuran siput maka semakin berat pula tubuhnya. Hal tersebut sesuai dengan pertumbuhan bagi siput. Panjang dan berat siput dapat menentukan usia dari siput tersebut, semakin panjang dan berat maka usia siput akan semakin dewasa.

Berbeda dengan hasil analisis korelasi yang ditunjukkan pada Tabel 3, bahwa tidak terdapat korelasi antara berat tubuh T. palustris dengan jumlah seresah yang diurai. Berbeda dengan T. sulcata, terdapat korelasi antara berat tubuhnya dengan jumlah seresah yang diurai. Hasil tersebut menunjukkan bahwa semakin berat tubuh siput T. sulcata maka semakin banyak pula jumlah seresah yang diurainya.

Jika T. palustris dibandingkan T. sulcata, tampak bahwa walaupun tubuh $T$. sulcata lebih kecil dari $T$. palustris namun ia mampu mengurai lebih banyak dibandingkan T. palustris. Jika mengacu pada hasil penelitian Patria \& Putri (2017), karbon yang tersimpan dalam cangkang $T$. sulcata < karbon cangkang $T$. palustris maka dapat diasumsikan kemungkinan bahwa karbon yang terakumulasi dalam cangkang $T$. sulcata lebih kecil dibandingkan dengan karbon yang terdapat dalam tubuh lunaknya.

\section{KESIMPULAN}

Terebralia palustris mampu mengurai daun sebesar $3,48 \% \pm 0,18$ /hari untuk $R$. apiculata dan $8,28 \% \pm 0,13$ /hari untuk $R$. stylosa, sedangkan T. sulcata mengurai daun rata-rata sebesar $4,07 \% \pm 0,12$ /hari untuk $R$. apiculata dan 4,93\% 0,15/hari untuk $R$. stylosa.

Hasil penelitian juga menunjukkan bahwa tidak 
ditemukan korelasi antara panjang dan berat $T$. palustris dengan persentase penguraiannya. Begitu pula dengan T. sulcata, tidak ditemukan korelasi antara berat dengan laju penguraiannya. Sebaliknya, terdapat korelasi antara panjang dengan persentase penguraiannya.

\section{UCAPAN TERIMA KASIH}

Penulis mengucapkan terima kasih kepada Jurnal Kelautan dan Perikanan Terapan.

\section{DAFTAR PUSTAKA}

Ashton, E.C., Hogarth, P.J., \& Ormond, R. (1999). Breakdown of mangrove leaf litter in a managed mangrove forest in Pennisular Malaysia. Hydrobiologia 413: 77-88.

Boonruang, P. (1984). The rate of degradation of mangrove leaves, Rhizopora apiculata BL and Avicennia marina (FORSK) VIERH at Phuket Island, Western Peninsula of Thailand. Proceeding of Asian Symposium Mangrove Environment Research and Management. University of Malaya, Kuala Lumpur: 200-208.

Bouillon, S., Connolly, R.M., \& Lee, S.Y. (2008). Organic matter exchange and cycling in mangrove ecosystem: recent insight from stable isotope studies. Journal of Sea Research 59: 44-58

Cannicci, S., Burrows, D., Fratini, S., Smith III, T.J., Offenberg, J., \& Dahdouh-Guebas, F. (2008). Faunal impact on vegetation structure and ecosystem function in mangrove forests: a review. Aquatic Botany 89: 186-200.

Choong, V. C., Sesakumar, A., Leh, M.U.C., \& Cruz, R.D. (1992). The fish and prawn communities of a Malaysian coastal mangrove system, with comparisons to adjacent mud flats and inshore waters. Estuarine, Coastal and Shelf Science 31: 703722.

Fratini, S., Cannicci, S., \& Vannini, M. (2001). Feeding clusters and olfaction in the mangrove snail Terebralia palustris (Linnaeus) (Potamididae: Gastropoda). Journal of Experimental Marine Biology and Ecology 261: 173-183.

Fratini, S., Vigiani, V., Cannicci, S., \& Vannini, M. (2004). Terebralia palustris (Gastropoda Potamididae) in a Kenyan mangal: size structure, distribution and impact on the consumption of leaf litter. Marine Biology 144: 1173-1182.

Griffiths, H. (1998). Stable isotopes: integration of biological, ecological, and geochemical processes. BIOS Scientific Publishers, Oxford: 438 hlm.

Houbrick, R.S. (1991). Systematic review and functional morphology of the mangrove snails Terebralia and Telescopium (Potamididae;
Prosobranchia). Malacologia33(1-2): 289-338.

Kauffman, J.B., \& Donato, D.C. (2012). Protocols for the measurement, monitoring and reporting of structure, biomass and carbon stocks in mangrove forests. Working Paper 86. CIFOR, Bogor: vi + $40 \mathrm{hlm}$.

Lestarina, P.M. (2011). Produktivitas serasah mangrove dan potensi kontribusi unsur hara di perairan mangrove Pulau Panjang, Banten. Thesis. Program Studi Ilmu Kelautan. IPB, Bogor: ix $+51 \mathrm{hlm}$.

Mason, C.F. (2004). Decomposition. The Edward Arnold (Publ) Ltd. Southmpton. London: 86-90.

McCutchan Jr. J.H., Lewis, W.M., Kendall, C., \& McGrath, C.C. (2003). Variation in trophic shift for stable isotope ratios of carbon, nitrogen, and sulfur. Oikos 102 (2): 378-390.

Penha-Lopes., Bouillon, G. S., Mangion, P., Macia, A., \& Paula, J. (2009). Population structure, density and food sources of Terebralia palustris (Potamididae: Gastropoda) in a low intertidal Avicennia marina mangrove stand (Inhaca Island, Mozambique). Estuarine, Coastal and Shelf Science 84: 318-325.

Patria, M.P., \& Putri, S.A. (2017). The role of Terebralia (Gastropoda: Potamididae) in carbon deposits at mangrove forest Pulau Panjang, Serang-Banten. AIP Conference Proceedings 1844 (1), 040002

Pramudji. (2001). Ekosistem hutan mangrove dan peranannya sebagai habitat berbagai fauna aquatik. Oseana 26 (4): 13-23.

Rao, R.S., Woitchik, A.F., Goeyens, L., Van Riet, A., Kazungu, D., \& Dehairs, F. (1994). Carbon, nitrogen contents and stable isotope abundance in mangrove leaves from an east African coastal lagoon (Kenya). Aquat. Bot 47: 175-183

Schmidt, O., Scrimgeour, C.M., \& Curry, J.P. (1999). Carbon and nitrogen stable isotope ratios in body tissue and mucus of feeding and fasting earthworms (Lumbricus festivus). Oecologia 118: 915.

Slim, F.., M.A. Hemminga, C. Ochieng, N.T. Jannink, E. Cocheret de la Moriniere \& G. van der Velde. (1997). Leaf litter removal by the snails Terebralia palustris (Linnaeus) and sesarmid crabs in an East African mangrove forest (Gazi Bay, Kenya). J Exp Mar Biol Ecol 215: 35-48.

Soemodihardjo,S., \& Kastoro, W. (1977). Notes on the Terebralia palustris (Gastropoda) from the coral island in the Jakarta Bay area. Mar Res Indonesia 18:131-148.

Tue, N.T., Hamaoka, H., Sogabe, A., Quy, T.D., Nhuan, M.T., \& Omori, K. (2012). Food sources of macroinvertebrates in an important mangrove ecosystem of Vietnam determined by dual stable iso- 
tope signatures. Journal of Sea Research 72: 1421.

Wells, F.E \& C.M. Lalli. (2003). Aspects of the ecology of the mudwhelks Terebraliapalustris and $T$. semistriata in northwestern Australia. The Marine Flora and fauna of Dampier, Western Australia: 193-208.

Lampiran 1. Data Hasil Penguraian Serasah (RA: R. apiculata, RS: R. stylosa, TP: T. palustris, TS: T. sulcata) Appendix 1. Data on Decomposition of Litter (RA: R. apiculata, RS: R. stylosa, TP: T. palustris, TS: T. sulcata)

\begin{tabular}{|c|c|c|c|c|c|c|}
\hline Perlakuan & $\begin{array}{c}\text { Panjang } \\
\text { (g) }\end{array}$ & $\begin{array}{c}\text { Berat } \\
\text { Moluska } \\
\text { (g) }\end{array}$ & $\begin{array}{c}\text { Berat } \\
\text { Awal } \\
\text { Serasah } \\
\end{array}$ & $\begin{array}{c}\text { Berat } \\
\text { Akhir } \\
\text { Serasah } \\
\end{array}$ & $\begin{array}{c}\text { Jumlah } \\
\text { Serasah yang } \\
\text { Diurai (g) }\end{array}$ & $\begin{array}{c}\text { Jumlah } \\
\text { Serasah yang } \\
\text { Diurai (\%) }\end{array}$ \\
\hline \multirow[t]{10}{*}{ RA--TP } & 6.12 & 12.11 & 3.35 & 3.05 & 0.3 & 8.95 \\
\hline & 5.34 & 7.68 & 2.76 & 2.46 & 0.3 & 10.86 \\
\hline & 6.12 & 12.28 & 1.78 & 1.42 & 0.36 & 20.22 \\
\hline & 6.27 & 11.27 & 2.43 & 1.97 & 0.46 & 18.93 \\
\hline & 5.44 & 9.03 & 2 & 1.11 & 0.89 & 44.50 \\
\hline & 5.73 & 10.71 & 1.22 & 1.09 & 0.13 & 10.65 \\
\hline & 5.73 & 9.19 & 2.49 & 1.25 & 1.24 & 49.79 \\
\hline & 5.38 & 7.19 & 2.1 & 0.88 & 1.22 & 58.09 \\
\hline & 7.11 & 18.17 & 2.54 & 1.65 & 0.89 & 35.03 \\
\hline & 7 & 14.68 & 2.51 & 2.28 & 0.23 & 9.16 \\
\hline Rata-rata & 6.024 & 11.231 & 2.318 & 1.716 & 0.602 & 26.62 \\
\hline \multirow[t]{10}{*}{ RA--TS } & 3.43 & 3.46 & 1.73 & 1.41 & 0.32 & 18.49 \\
\hline & 3.61 & 3.81 & 1.81 & 1 & 0.81 & 44.75 \\
\hline & 3.22 & 3.33 & 1.78 & 1.43 & 0.35 & 19.66 \\
\hline & 3.44 & 3.27 & 2.52 & 1.81 & 0.71 & 28.17 \\
\hline & 3.74 & 3.7 & 3.03 & 2.23 & 0.8 & 26.40 \\
\hline & 3.23 & 2.97 & 2.08 & 1.2 & 0.88 & 42.30 \\
\hline & 3.27 & 2.7 & 3.26 & 1.88 & 1.38 & 42.33 \\
\hline & 3.13 & 2.56 & 2.06 & 1.7 & 0.36 & 17.47 \\
\hline & 3.1 & 2.01 & 1.54 & 1.45 & 0.09 & 5.84 \\
\hline & 3.55 & 2.76 & 1.05 & 0.77 & 0.28 & 26.66 \\
\hline Rata-rata & 3.372 & 3.057 & 2.086 & 1.488 & 0.598 & 27.21 \\
\hline \multirow[t]{10}{*}{ RS--TP } & 7.11 & 16.58 & 2.89 & 1.58 & 1.31 & 45.32 \\
\hline & 7.83 & 24.2 & 2.57 & 1.46 & 1.11 & 43.19 \\
\hline & 8.56 & 31.92 & 2.07 & 1.12 & 0.95 & 45.89 \\
\hline & 7.12 & 19.13 & 2.27 & 1.87 & 0.4 & 17.62 \\
\hline & 8.41 & 34.15 & 3.07 & 2.51 & 0.56 & 18.24 \\
\hline & 6.98 & 23.35 & 3.27 & 2.63 & 0.64 & 19.57 \\
\hline & 7.31 & 24 & 2.25 & 1.84 & 0.41 & 18.22 \\
\hline & 7.11 & 23.06 & 2.72 & 1.56 & 1.16 & 42.64 \\
\hline & 7.84 & 28.56 & 4.33 & 3.73 & 0.6 & 13.85 \\
\hline & 6.72 & 21.74 & 2.37 & 1.6 & 0.77 & 32.48 \\
\hline Rata-rata & 7.499 & 24.669 & 2.781 & 1.99 & 0.791 & 29.70 \\
\hline \multirow[t]{10}{*}{ RS--TS } & 3.12 & 2.57 & 1.88 & 1.62 & 0.26 & 13.82 \\
\hline & 3.39 & 2.89 & 2.16 & 1.67 & 0.49 & 22.68 \\
\hline & 3.31 & 3.3 & 1.65 & 0.97 & 0.68 & 41.21 \\
\hline & 3.31 & 3.28 & 2.35 & 2.06 & 0.29 & 12.34 \\
\hline & 3.32 & 3.24 & 2.09 & 1.38 & 0.71 & 33.97 \\
\hline & 3.22 & 2.69 & 1.43 & 0.79 & 0.64 & 44.75 \\
\hline & 3.44 & 2.84 & 1.31 & 0.66 & 0.65 & 49.61 \\
\hline & 3.38 & 2.77 & 2.89 & 2.23 & 0.66 & 22.83 \\
\hline & 3 & 2.24 & 2.41 & 2.1 & 0.31 & 12.86 \\
\hline & 3.1 & 2.6 & 1.27 & 1.15 & 0.12 & 9.44 \\
\hline Rata-rata & 3.259 & 2.842 & 1.944 & 1.463 & 0.481 & 26.35 \\
\hline
\end{tabular}


Lampiran 2. Data Kontrol

Appendix 2. Control Data

\begin{tabular}{|c|c|c|c|c|}
\hline Perlakuan & $\begin{array}{c}\text { Berat Awal } \\
\text { Daun (g) }\end{array}$ & $\begin{array}{c}\text { Berat Akhir } \\
\text { Daun (g) }\end{array}$ & $\begin{array}{c}\text { Jumlah } \\
\text { Daun yang } \\
\text { Diurai (g) }\end{array}$ & $\begin{array}{c}\text { Jumlah Daun } \\
\text { yang Diurai } \\
(\%)\end{array}$ \\
\hline \multirow[t]{10}{*}{$\begin{array}{l}\text { Rhizopora } \\
\text { stylosa }\end{array}$} & 2.33 & 1.89 & 0.44 & 18.88 \\
\hline & 1.98 & 1.42 & 0.56 & 28.28 \\
\hline & 2.23 & 1.46 & 0.77 & 34.52 \\
\hline & 1.68 & 1.65 & 0.03 & 1.78 \\
\hline & 3.48 & 3.09 & 0.39 & 11.20 \\
\hline & 2.5 & 1.81 & 0.69 & 27.6 \\
\hline & 3.47 & 1.97 & 1.5 & 43.22 \\
\hline & 1.46 & 1.21 & 0.25 & 17.12 \\
\hline & 2.97 & 2.26 & 0.71 & 23.90 \\
\hline & 2.99 & 2.76 & 0.23 & 7.69 \\
\hline Rata-rata & 2.50 & 1.95 & 0.55 & 21.42 \\
\hline \multirow[t]{10}{*}{$\begin{array}{l}\text { Rhizopora } \\
\text { apiculata }\end{array}$} & 4.54 & 3.48 & 1.06 & 23.34 \\
\hline & 1.7 & 1.54 & 0.16 & 9.41 \\
\hline & 1.17 & 0.9 & 0.27 & 23.07 \\
\hline & 1.61 & 1.24 & 0.37 & 22.98 \\
\hline & 1.38 & 1.12 & 0.26 & 18.84 \\
\hline & 1.86 & 1.1 & 0.76 & 40.86 \\
\hline & 1.78 & 1.25 & 0.53 & 29.77 \\
\hline & 1.57 & 1.15 & 0.42 & 26.75 \\
\hline & 2.1 & 1.64 & 0.46 & 21.90 \\
\hline & 1.52 & 1.3 & 0.22 & 14.47 \\
\hline Rata-rata & 1.92 & 1.47 & 0.45 & 23.14 \\
\hline
\end{tabular}

